\title{
Effect of FSH and eCG on Alpaca (Vicugna pacos) Oocyte Maturation in vitro
}

\author{
US Quispe-Gutiérrez $^{1 *}$, LV Olivera-Marocho², $\mathrm{J} \mathrm{Ccopa-Ccallata}^{3}$, LE Pahuara-Farfan ${ }^{3}$, M Barragán- \\ Condori $^{4}$ and JL Berndtson ${ }^{5}$
}

${ }^{1}$ Faculty of Veterinary Medicine and Zootechnics, Micaela Bastidas National University of Apurimac, Abancay, Apurimac, Peru ${ }^{2}$ Faculty of Veterinary Medicine and Zootechnics, National University of Altiplano, Puno, Peru; ${ }^{3}$ National Institute of Agricultural Innovation (INIA), Illpa Puno Agricultural Experimental Station, Quimsachata annex, Puno, Peru; ${ }^{4}$ Academic Department of Civil Engineering and Basic Sciences, National Intercultural University of Quillabamba, Cusco, Peru: ${ }^{5}$ University of Wisconsin, Madison, Department of Animal Sciences, WI, USA

*Corresponding author: usquispe@unamba.edu.pe

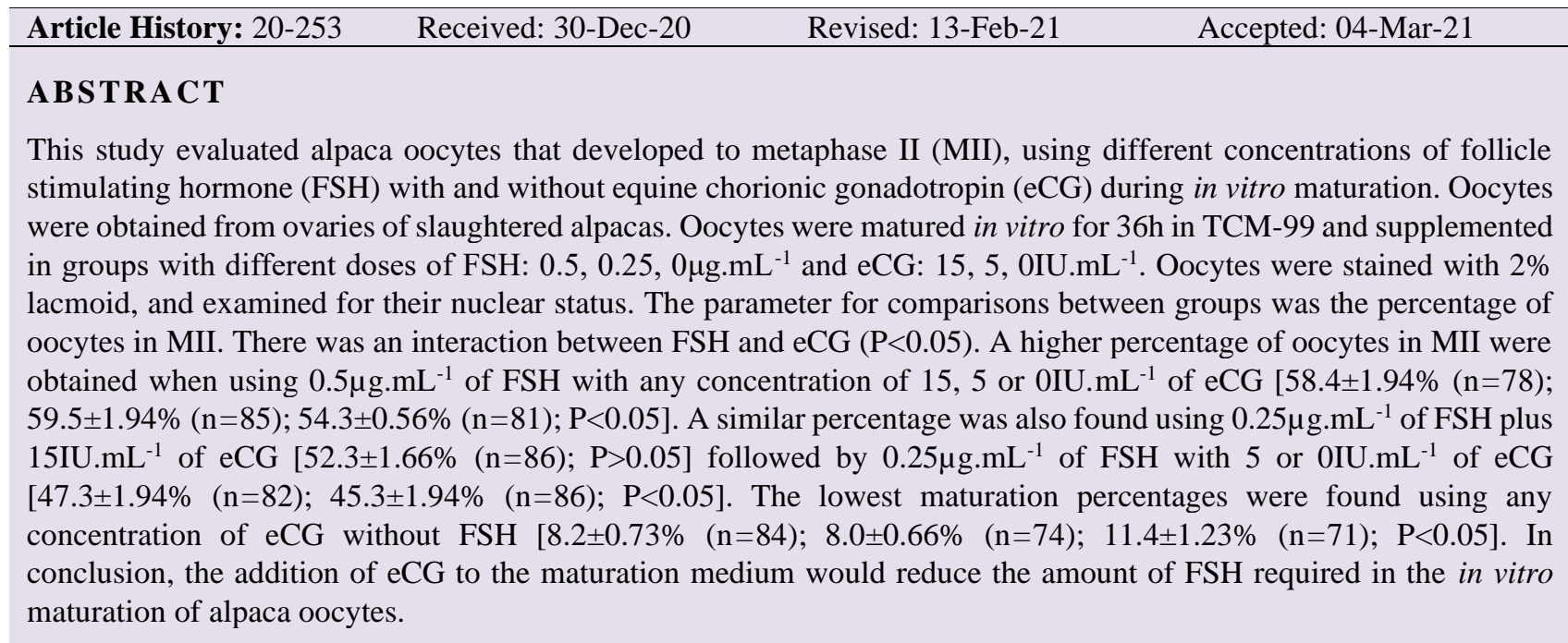

Key words: Camelid, Equine chorionic gonadotropin, Follicle stimulating hormone, Metaphase II.

C202I IJVS - All Rights Reserved

\section{INTRODUCTION}

Alpacas play an important social and economic role in rural families in some South American countries. This has expanded to other areas of the world in recent years, largely due to the production of fine fiber (Sumar 2007; Aba 2014). However, fertility is a constant issue as about $20 \%$ of alpacas do not become pregnant after mating (Brown 2000) and the interval between births is long, resulting in few offspring obtained during their reproductive life. Thus, genetic improvement to obtain high-quality animals traditionally requires several years. Further, the complex reproductive patterns in this species have slowed advancement of reproductive technologies, which are necessary to raise the rate of genetic improvement and improve fertility issues in alpacas (Miragaya et al. 2006).
In vitro embryo production can improve genetic progress (Mutembei et al. 2016). However, it is not yet efficient in camelids, as this technology in alpacas progresses slowly when compared to other traditional livestock species (Tibary et al. 2005) and development is in the initial stages (Leisinger et al. 2014). There are several factors that limit optimal in vitro embryo production (Tibary et al. 2005), especially in vitro culture conditions which have not yet been addressed in camelids (Ratto et al. 2005). Oocyte maturation medium, a critical culture media for in vitro embryo production, is in the initial stages of research in camelids. Maturation medium without supplementation of gonadotropins results in low maturation rates of oocytes (Galli and Moor 1991; Wang et al. 2013). The in vitro maturation of oocytes in camelids is still incipient and remains a challenge to achieve the expected success (Wani 2021).

Cite This Article as: Quispe-Gutiérrez US, Olivera-Marocho LV, Ccopa-Ccallata J, Pahuara-Farfan LE, BarragánCondori M and Berndtson JL, 2021. Effect of FSH and eCG on alpaca (Vicugna pacos) oocyte maturation in vitro. International Journal of Veterinary Science 10(3): 156-161. https://doi.org/10.47278/journal.ijvs/2021.050 
Previous studies in alpacas used $0.5 \mu \mathrm{g} \cdot \mathrm{mL}^{-1}$ of FSH as a supplement in maturation medium at a fixed concentration during in vitro maturation of oocytes (Ratto et al. 2007; Huanca et al. 2014; Ruiz et al. 2017), in this process, the use of eCG in alpacas is not typical. However, in other species, different concentrations of gonadotropins in maturation medium have been studied (Choi et al. 2001; Farag et al. 2012; Wei et al. 2017; Wei et al. 2018). In dromedary camels, a high in vitro maturation rate of oocytes was reported when supplemented with $10 \mu \mathrm{g} . \mathrm{mL}^{-1}$ of pregnant mare serum gonadotropin (PMSG) plus human chorionic gonadotropin (Farag et al. 2012; Farag et al. 2013). Also, when they used higher concentrations of eCG, the in vitro maturation of ewe oocytes increased (Wei et al. 2016). Similarly, in canines, short exposure of oocytes to $0.5 \mathrm{IU} . \mathrm{mL}^{-1}$ of eCG improved the maturation rate in vitro (Songsasen et al. 2003). Likewise, with higher doses of $\mathrm{FSH}$, the cumulus expansion of bovine oocytes increased in a dose-dependent manner in in vitro culture (Choi et al. 2001). This FSH improves maturation and decreases oocyte apoptosis, increases the expression of FSH, LH, and GnRH receptors, which can facilitate in vitro maturation of oocytes (Wei et al. 2016; Ondho et al. 2020). Thus, FSH induces the expansion of cumulus cells and nuclear maturation of the oocyte (Yang et al. 2016). eCG acts similarly to FSH and LH (Murphy and Martinuk 1991) by primarily binding to $\mathrm{FSH}$ receptors in non-equid species (Murphy 2012). Consequently, FSH and eCG together would participate in the in vitro maturation process of alpaca oocytes.

The effects of different concentrations of FSH and eCG during in vitro maturation of alpaca oocytes are still unclear. We hypothesize that when combining FSH with eCG, similar in vitro maturation rates of alpaca oocytes are obtained as opposed to using high concentrations of FSH in maturation medium. This study aimed to evaluate the in vitro development of alpaca oocytes to MII, using maturation medium supplemented with different concentrations of FSH and eCG.

\section{MATERIALS AND METHODS}

All products were acquired from Sigma Chemical Co, unless otherwise declared. This study was carried out in 2018 between January and April - the reproductive season of alpacas.

All the procedures were authorized by the Animal Use Committee, in vitro Fertilization Laboratory of the Quimsachata Research and Production Center of ILLPA Puno Experimental Station, INIA, Peru (LFIV/Q/INIA/1201-17).

\section{Obtaining Ovaries, Recovery and Evaluating Oocytes}

Ovaries from non-pregnant adult Huacaya alpacas were obtained from local abattoirs in Puno, Peru immediately after slaughter, then transported in $0.9 \%$ sodium chloride solution, supplemented with $100 \mathrm{mg} . \mathrm{L}^{-1}$ streptomycin, 100,000IU.L $\mathrm{L}^{-1}$ penicillin, and $250 \mu \mathrm{g} . \mathrm{L}^{-1}$ amphotericin $\mathrm{B}$, at $35-37^{\circ} \mathrm{C}$ for 6 to $8 \mathrm{~h}$, to the in vitro Fertilization Laboratory of the Quimsachata Research and Production Center of ILLPA Puno Experimental Station,

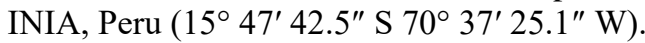

Oocytes were recovered by individual follicular sections. Follicles of approximately 2 to $6 \mathrm{~mm}$ in diameter were sectioned and follicular content drained into a Petri dish containing phosphate-buffered saline (PBS) plus $2 \%$ bovine serum albumin (BSA), maintained at $37^{\circ} \mathrm{C}$. These oocytes were selected under a stereomicroscope (Meiji Techno) at $2 \mathrm{x}$ or $4 \mathrm{x}$ with plate temperature regulated at $37^{\circ} \mathrm{C}$, then washed in four successive drops of PBS + BSA Oocyte evaluation was performed according to the quantity of cumulus cell layers and the appearance of the oocyte cytoplasm, according to the previous description by Hawk and Wall (1994), which classifies oocytes into three types (Fig. 1), category A: good quality (compact cumulus, with full cumulus or several layers of cumulus cells; cytoplasm even, dense, finely granulated); category B: intermediate quality (compact cumulus, a few to several layers, covering all or at least half of zona pellucida; cytoplasm from even, dense, finely granulated to moderate size granules), and category C: rejected (partially expanded or fully expanded and dispersing cumulus, non-cellular framework with no cumulus cells; extraordinarily small or large oocyte, discolored cumulus, corona radiata with no cumulus, nude oocytes; cytoplasm coarse granular or intermixed very light and very dark areas, discolored cytoplasm, badly distorted oocytes).

\section{In vitro Maturation}

FSH (Folltropin-V; Bioniche Animal Health, Canada) and eCG (Folligon®, MSD, Animal Health) were used as supplements to in vitro maturation media. Category A and B alpaca oocytes $(n=890)$ were randomly divided using a $3 \times 3$ factorial arrangement to determine the effect of FSH

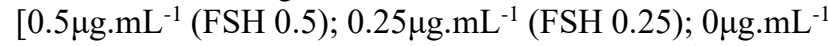
(FSH 0)] or eCG [15IU.mL ${ }^{-1}$ (eCG 15); 5IU.mL ${ }^{-1}$ (eCG 5); 0IU.mL $\mathrm{m}^{-1}$ (eCG 0)]. The experiment was replicated 5 times, assigning a total of 105, 95, 102, 98, 95, 104, 109, 92 and 90 oocytes to: a) FSH 0.5 + eCG 15 ; b) FSH 0.5 + eCG 5; c) FSH 0.5 + eCG 0; d) FSH 0.25 + eCG 15; e) FSH 0.25 + eCG 5; f) FSH 0.25 + eCG 0; g) FSH 0 + eCG 15; h) FSH $0+\mathrm{eCG} 5$, and i) FSH $0+$ eCG 0 , respectively.

Selected oocytes were washed four times in successive drops of Tissue Culture Medium 199 (TCM-199), then transferred to maturation medium composed of TCM-199 with $10 \mathrm{mM}$ HEPES, $2.0 \mathrm{mM} \mathrm{NaHC} 03$ supplemented with $10 \%$ fetal bovine serum, $0.6 \mathrm{mM}$ cysteine, $0.25 \mathrm{mM}$ glutamine, $0.2 \mathrm{mM}$ sodium pyruvate, 10ng. $\mathrm{mL}^{-1} \mathrm{EGF}$; $1 \mu \mathrm{g} \cdot \mathrm{mL}^{-1}$ of $17 \beta$-estradiol, $5 \mu \mathrm{g} \cdot \mathrm{mL}^{-1}$ of $\mathrm{LH}, \mathrm{FSH}(0.5$ or 0.25 or $\left.0 \mu \mathrm{g} \cdot \mathrm{mL}^{-1}\right)$, eCG $\left(15\right.$ or 5 or $\left.0 \mathrm{IU} \cdot \mathrm{mL}^{-1}\right)$, and 50 $\mu \mathrm{g} . \mathrm{mL}^{-1}$ of gentamicin. Oocytes were incubated in $80 \mu \mathrm{L}$ drops (8 to 16 oocytes per drop) in Petri dishes (30x15 mm) covered with mineral oil for $36 \mathrm{~h}$ at $38.2^{\circ} \mathrm{C}$, with $6.1 \% \mathrm{CO}_{2}$, $5 \% \mathrm{O}_{2}$ and high humidity.

\section{Assessment of Oocyte Maturation}

Oocyte maturation was evaluated as previously described by Ruiz et al. (2017) with certain modifications. Oocytes were removed from the incubator and placed in drops of PBS and transferred to $0.5 \mathrm{~mL}$ vials. After maturation vortex agitation for $3 \mathrm{~min}$ separated the cumulus cells from the oocytes. Oocytes were washed in drops of PBS and placed in a fixative solution composed of acetic acid/ethanol (1:3; v:v) for $48 \mathrm{~h}$.

Oocyte staining was performed according to the previous description by Huanca et al. (2014) with some modifications. The oocytes in groups of 5 to 10 were 
immersed in PBS, placed onto a slide, covered with a coverslip, and vaseline was placed at the corners of the coverslip to avoid contact. Oocytes were stained with $2 \%$ (w:v) lacmoid in $45 \%$ (v:v) acetic acid, and examined at 400x magnification for their nuclear status. Some oocytes were lost during the pipetting procedure post maturation, leaving for evaluation a total of $78,85,81,86,82,86,84$, 74 and 71 oocytes per treatment group [a) FSH $0.5+$ eCG 15 , b) FSH $0.5+$ eCG 5, c) FSH $0.5+$ eCG 0, d) FSH 0.25 + eCG 15, e) FSH 0.25 + eCG 5, f) FSH 0.25 + eCG 0, g) FSH $0+$ eCG 15, h) FSH $0+$ eCG 5 and i) FSH $0+$ eCG 0 , respectively]. The oocytes classification was executed as described by Ratto et al. (2005) as: germinal vesicle (GV), germinal vesicle breakdown (GVBD), metaphase I (MI), metaphase II (MII), and degenerate (DG). Metaphase II oocytes were considered to have reached nuclear maturation (Fig.1).

\section{Statistical Analysis}

The data were converted to angular values or square root, fulfilling the assumptions of normality and homoscedasticity. The analysis of variance with a $3 \times 3$ factorial arrangement was performed considering as factors: FSH $\left(0.5,0.25\right.$ or $\left.0 \mu \mathrm{g} . \mathrm{mL}^{-1}\right)$ and eCG $(15,5$ or 0IU.mL ${ }^{-1}$ ) or their interaction. A Bonferroni test was used to contrast the differences between means, being considered significant when $\mathrm{P}<0.05$. The software used was InfoStat, version 2020e (Di Rienzo et al. 2008).

\section{RESULTS}

\section{Percentage of Metaphase II Stage Alpaca Oocyte}

Results are shown in Table 1. Considering MII stage oocytes, there was an interaction between FSH and eCG treatments $(\mathrm{P}<0.05)$. Higher $(\mathrm{P}<0.05)$ percentages of MII oocytes were obtained when using $0.5 \mu \mathrm{g} \cdot \mathrm{mL}^{-1}$ of $\mathrm{FSH}$ in combination with any concentration 15,5 or $0 \mathrm{IU} \cdot \mathrm{mL}^{-1}$ of eCG (54.3 \pm 0.56 to $59.5 \pm 1.94 \%)$. Similar percentages were found using $0.25 \mu \mathrm{g} . \mathrm{mL}^{-1}$ of FSH plus $15 \mathrm{IU} . \mathrm{mL}^{-1}$ of eCG. A lower $(\mathrm{P}<0.05)$ percentage of MII oocytes was found using $0.25 \mu \mathrm{g} . \mathrm{mL}^{-1}$ of FSH plus 5 or $0 \mathrm{IU} . \mathrm{mL}^{-1}$ of eCG, and a much lower percentage $(\mathrm{P}<0.05)$ in groups using $0 \mu \mathrm{g} . \mathrm{mL}^{-}$ ${ }^{1}$ of FSH with any 15,5 or $0 \mathrm{IU} . \mathrm{mL}^{-1}$ concentration of eCG (8.0 \pm 0.66 to $11.4 \pm 1.23 \%)$.

Percentage of germinal vesicle, germinal vesicle breakdown, metaphase I and degenerate stage alpaca oocytes.

Results are shown in Table 1. There was no interaction $(\mathrm{P}>0.05)$ between $\mathrm{FSH}$ and eCG on $\mathrm{MI}$, GVBD, GV, or DG; while MI, GVBD, and DG were affected by FSH $(\mathrm{P}<0.05)$. Neither FSH nor eCG had an effect $(\mathrm{P}>0.05)$ on $\mathrm{GV}$. A higher $(\mathrm{P}<0.05)$ percentage of development to MI was obtained using 0.25 or $0.5 \mu \mathrm{g} . \mathrm{mL}^{-}$ ${ }^{1}$ of FSH either with or without eCG versus 0 or 5 or 15UI.mL ${ }^{-1}$ of eCG without FSH. A lower $(\mathrm{P}<0.05)$ percentage of GVBD was found using $0.5 \mu \mathrm{g} \cdot \mathrm{mL}^{-1}$ of FSH with or without eCG compared to $0.25 \mu \mathrm{g} \cdot \mathrm{mL}^{-1}$ of FSH with or without eCG and $0 \mu \mathrm{g} \cdot \mathrm{mL}^{-1}$ of $\mathrm{FSH}$ with or without eCG. Also, a lower $(\mathrm{P}<0.05)$ percentage of $\mathrm{DG}$ oocytes were obtained when using 0.5 or $0.25 \mu \mathrm{g} . \mathrm{mL}^{-1}$ of FSH with or without eCG compared to groups 0,5 or $15 \mathrm{UI} . \mathrm{mL}^{-1}$ of eCG without FSH. Finally, the percentages of GV for each group were similar $(\mathrm{P}>0.05)$.
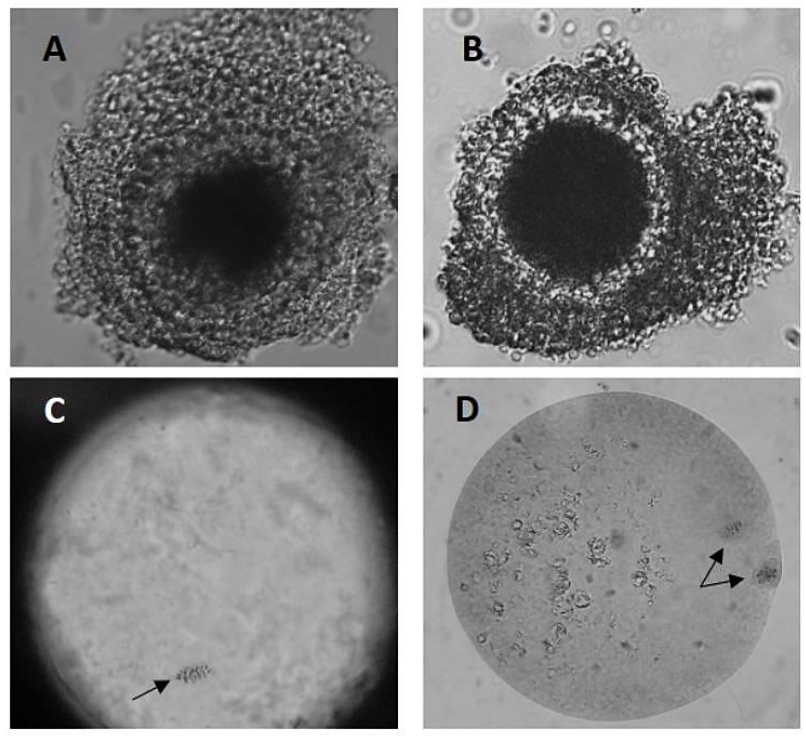

Fig. 1: Alpaca oocytes before and during in vitro maturation. A: Compact cumulus oocyte complex with $\geq 5$ layers of cumulus cells with homogeneous cytoplasm (category A), B: Cumulus oocyte complex with few layers of cumulus cells with inhomogeneous cytoplasm (category B), C: Chromosomes in Metaphase I (MI), D: Oocyte in Metaphase II (MII).

\section{DISCUSSION}

The hypothesis of this study was that supplementation of in vitro maturation medium with both $\mathrm{FSH}$ and $\mathrm{eCG}$, as opposed to high concentrations of FSH, would result in similar maturation rates of alpaca oocytes. This study shows that maturation medium supplemented with FSH and eCG influenced the percentage of alpaca oocytes in the MII stage. When using $0.25 \mu \mathrm{g} \cdot \mathrm{mL}^{-1}$ of FSH plus $15 \mathrm{IU} . \mathrm{mL}$ ${ }^{1}$ of eCG, $52.3 \%$ of oocytes maturated to MII stage, similar to the maturation rates ( 54.3 to $59.5 \%)$ obtained with concentrations of $0.5 \mu \mathrm{g} \cdot \mathrm{mL}^{-1}$ of FSH plus 15,5 or $0 \mathrm{IU} . \mathrm{mL}$ ${ }^{1}$ of eCG.

Previous studies using higher concentrations of FSH $\left(0.5 \mu \mathrm{g} . \mathrm{mL}^{-1}\right)$ allowed similar maturation rates, such as $5 \mu \mathrm{g} . \mathrm{mL}^{-1}$ of FSH in llamas (Sansinena et al. 2003); 10 $\mu \mathrm{g} . \mathrm{mL}^{-1}$ of b-FSH and b-LH in dromedary camels (Nowshari, 2005). However, other studies have shown higher rates of maturation of oocytes when using $0.5 \mu \mathrm{g} . \mathrm{mL}^{-1}$ of FSH in alpacas (Ratto et al. 2007; Huanca et al. 2014; Ruiz et al. 2017) and llamas (Ratto et al. 2005). However, the same concentration of FSH, $0.5 \mu \mathrm{g} . \mathrm{mL}^{-1}$, has resulted in lower rates of maturation in llamas (Del Campo et al. 1994). Similarly, in ewes the rate of oocyte maturation varies amongst different concentrations of FSH (Wei et al. 2017; Wei et al. 2018).

In this study, lower oocyte maturation rates (45.3 and $47.3 \%$ ) were found when using concentrations of $0.25 \mu \mathrm{g} . \mathrm{mL}^{-1}$ of FSH plus 5 or $0 \mathrm{IU} \cdot \mathrm{mL}^{-1}$ of eCG. These results suggest that when using low concentrations of gonadotropins, the rates of oocyte maturation decrease, as reported by Leisinger et al. (2014), in which $15 \mathrm{ng} . \mu \mathrm{L}^{-1}$ of FSH resulted in a $37.9 \%$ maturation rate of alpaca oocytes. In groups without FSH supplemented with any concentration of eCG, maturation percentages were low ( 8.0 to $11.4 \%$ ). These results suggest that supplementation with eCG without FSH in maturation medium would not be 
Int J Vet Sci, 2021, 10(3): 156-161.

Table 1: Percentage (mean \pm SEM) of development to metaphase II of alpaca oocytes, using different concentrations of FSH and eCG during in vitro maturation (replicates $=5$ ).

\begin{tabular}{|c|c|c|c|c|c|c|c|}
\hline \multirow{2}{*}{$\begin{array}{l}\text { Treatment } \\
\text { FSH }\end{array}$} & \multirow{2}{*}{ eCG } & \multicolumn{2}{|l|}{ Oocyte } & \multicolumn{3}{|c|}{ Nuclear maturation stage (mean \pm SEM) } & \multirow[b]{3}{*}{ DG } \\
\hline & & $\mathrm{n}$ & & & & & \\
\hline$\mu \mathrm{g} . \mathrm{mL}^{-1}$ & UI.mL $L^{-1}$ & & GV & GVBD & MI & MII & \\
\hline 0 & 0 & 71 & $5.2 \pm 1.33$ & $36.6 \pm 0.40^{\mathrm{a}}$ & $8.7 \pm 1.19^{\mathrm{a}}$ & $11.4 \pm 1.23^{\mathrm{a}}$ & $38.1 \pm 1.25^{\mathrm{a}}$ \\
\hline 0 & 5 & 74 & $9.4 \pm 1.14$ & $37.6 \pm 2.07^{\mathrm{a}}$ & $9.4 \pm 1.14^{\mathrm{a}}$ & $8.0 \pm 0.66^{\mathrm{a}}$ & $35.7 \pm 1.95^{\mathrm{a}}$ \\
\hline 0 & 15 & 84 & $5.4 \pm 1.51$ & $39.0 \pm 2.07^{\mathrm{a}}$ & $9.5 \pm 0.93^{\mathrm{a}}$ & $8.2 \pm 0.73^{\mathrm{a}}$ & $38.0 \pm 1.80^{\mathrm{a}}$ \\
\hline 0.25 & 0 & 86 & $5.7 \pm 1.50$ & $16.4 \pm 1.54^{\mathrm{b}}$ & $18.7 \pm 1.57^{\mathrm{b}}$ & $45.3 \pm 1.94^{\mathrm{b}}$ & $13.9 \pm 1.06^{\mathrm{b}}$ \\
\hline 0.25 & 5 & 82 & $7.4 \pm 0.95$ & $15.9 \pm 0.44^{\mathrm{b}}$ & $18.3 \pm 1.20^{\mathrm{b}}$ & $47.3 \pm 1.94^{\mathrm{b}}$ & $11.2 \pm 1.55^{\mathrm{b}}$ \\
\hline 0.25 & 15 & 86 & $7.1 \pm 1.24$ & $13.9 \pm 0.66^{\mathrm{b}}$ & $16.2 \pm 1.51^{\mathrm{b}}$ & $52.3 \pm 1.66^{\mathrm{bc}}$ & $10.4 \pm 1.05^{\mathrm{b}}$ \\
\hline 0.5 & 0 & 81 & $4.8 \pm 1.33$ & $7.5 \pm 0.60^{c}$ & $19.7 \pm 1.01^{\mathrm{b}}$ & $54.3 \pm 0.56^{\mathrm{bc}}$ & $13.7 \pm 1.93^{\mathrm{b}}$ \\
\hline 0.5 & 5 & 85 & $4.6 \pm 1.28$ & $8.2 \pm 0.70^{c}$ & $17.6 \pm 1.04^{\mathrm{b}}$ & $59.5 \pm 1.94^{c}$ & $10.0 \pm 1.95^{\mathrm{b}}$ \\
\hline 0.5 & 15 & 78 & $7.8 \pm 0.64$ & $7.8 \pm 0.64^{\mathrm{c}}$ & $18.3 \pm 1.30^{\mathrm{b}}$ & $58.4 \pm 1.94^{\mathrm{c}}$ & $7.8 \pm 0.64^{\mathrm{b}}$ \\
\hline
\end{tabular}

GV=germinal vesicle, GVBD=germinal vesicle breakdown, MI=metaphase I, MII=metaphase II, DG=degenerate: Different superscript letters within the same column indicate statistical significance $(\mathrm{P}<0.05)$.

appropriate for alpaca oocytes. However, previous studies in other species reported high maturation rates of oocytes using $10 \mu \mathrm{g} . \mathrm{mL}^{-1}$ of PMSG in dromedary camels (Farag et

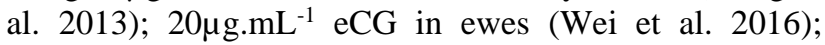
$0.5 \mathrm{IU} . \mathrm{mL}^{-1}$ of eCG in bitches (Songsasen et al. 2003). Consequently, the amount of eCG that should be used as a maturation medium supplement for alpaca oocytes remains controversial.

The observed differences of this study with respect to the others mentioned are likely attributable to the composition of maturation medium, including the content, and concentration of other hormones, macromolecules and the environment, among other factors. Differences between different culture media can be attributed to the composition of media, as well as differences in their ionic concentration (Farag et al. 2013). This assumes the composition of media used for the maturation of oocytes in vitro plays an integral role in oocyte development competence (Leisinger et al. 2014). Currently, different combinations of gonadotropins are utilized to try and improve in vitro maturation of oocytes; however, it is difficult to determine the dose to be used, especially in cases of combined protocols (Wang et al. 2013). Further, differences in oocyte culture environment could help explain differences between studies. Other investigations used 5\% oxygen and $5 \% \mathrm{CO}_{2}$ at 38 to $39^{\circ} \mathrm{C}$. However, this study utilized $6 \%$ oxygen and $6.1 \% \mathrm{CO}_{2}$ at $38.5^{\circ} \mathrm{C}$, similar to the reports by Leisinger et al. (2014), in which $6 \% \mathrm{CO}_{2}$ at $38^{\circ} \mathrm{C}$ was used in the incubation of alpaca oocytes. The in vitro environment used in the maturation of alpaca oocytes is still inadequate, therefore studies are needed to improve in vitro maturation protocols (Ruiz et al. 2017). Several elements or factors during in vitro maturation of camelid oocytes should be improved to achieve maturation rates similar to those obtained in other ruminants (Trasorras et al. 2014). Therefore, the ideal concentrations of FSH and eCG for in vitro maturation of alpaca oocytes are still unclear, requiring further studies involving other factors.

This study suggests a synergistic effect on the in vitro maturation of alpaca oocytes between 15IU. $\mathrm{mL}^{-1}$ of eCG and $0.25 \mu \mathrm{g} \cdot \mathrm{mL}^{-1}$ of FSH in the culture medium, likely due to both the FSH and LH activity of eCG (Murphy and Martinuk, 1991; Murphy, 2012). The positive action of eCG on the meiotic resumption in alpaca oocytes is likely related to FSH since the cumulus cells do not have LH receptors (Conti et al. 2006). eCG acts on intercellular gapjunctional communication (GJC) junctions between the oocyte and cumulus cells in addition to taking pathways similar to FSH; GJC closure is involved in meiotic resumption in in vitro maturation of porcine oocytes (Santiquet et al. 2012). In ewe oocytes, eCG improves maturation and reduces apoptosis of oocytes subjected to in vitro maturation and increases the expression of the FSH receptor that can facilitate in vitro maturation of oocytes (Wei et al. 2016). It could be possible that the combination of FSH and eCG in the in vitro maturation medium act on intracellular cAMP, favoring maturation or perhaps the developmental competence of the alpaca oocyte. Further studies are required to explain the synergistic effects of eCG with FSH on the in vitro maturation of alpaca oocytes.

Regarding previous stages of alpaca oocyte maturation, the percentages of MI development found in this study were similar to previous reports for alpacas (Ratto et al. 2007; Ruiz et al. 2017), llamas (Sansinena et al. 2003), and dromedary camels (Farag et al. 2013), but lower than in other dromedary camels (Nowshari, 2005). Likewise, the percentages of GVBD were similar to previous studies in llamas (Sansinena et al. 2003), but they differ from other reports in alpacas (Ratto et al. 2005; Ratto et al. 2007; Ruiz et al. 2017) and dromedary camels (Farag et al. 2013). The percentages of DG were similar to previous reports for alpacas (Ratto et al. 2007; Ruiz et al. 2017) and dromedary camels (Farag et al. 2013), but they are higher than other reports in alpacas (Huanca et al. 2014) and llamas (Ratto et al. 2005). The percentages of GV found in this study are in agreement with the results reported for alpacas (Huanca et al. 2014; Ruiz et al. 2017) and dromedary camels (Farag et al. 2013). The differences in the previous states of alpaca oocytes that lead to MII, among those found in this study compared to the other reports, would be attributed to the same factors described above for MII oocytes because they are sequential events that occur in the same environment cultivation.

In this study, gonadotropin supplementation resulted in a higher percentage of MI and GVBD, a lower percentage of DG, with no effect on GV; quantities that favored the highest percentage of MII from alpaca oocytes. Probably, the positive effect of the different concentrations of gonadotropins would modulate the amount of gene expression and pathway sequences that trigger the restart of oocyte meiosis until reaching MII. With the use of the gonadotropins (hCG, PMSG) several genes in cumulus cells are expressed during in vitro maturation of bovine oocytes (Salhab et al. 2011). Protein kinase $\mathrm{C}$ and mitogen- 
activated protein kinase (MAPK) are involved in FSHinduced GVBD of mouse cumulus-enclosed oocytes (Fan et al. 2004). Activation of MAPK in cumulus cells is essential for GVBD in cumulus-enclosed porcine oocytes (Liang et al. 2005). In the in vitro maturation of bovine oocytes, low doses of gonadotropins do not influence the expression of gene transcripts, but supplemented gonadotropins are imperative stimulating factors for oocyte maturation (Blaschka et al. 2019). FSH can enhance immature oocyte maturation in vitro in a dose-dependent manner; high doses of FSH cause a higher percentage of bovine oocytes in stage MII, and the adequate dose is 20IU.mL ${ }^{-1}$; on the other hand, FSH can regulate the synchronization of the oocyte in vitro maturation by postponing the change from MI to MII (Wang et al. 2013). The results suggest favorable effects of gonadotropins on the in vitro maturation of alpaca oocytes. However, the concentrations of gonadotropins that would be sufficient when used in in vitro maturation protocols are still not clear. This requires further studies with a molecular approach.

\section{Conclusion}

Higher percentages of MII alpaca oocytes were obtained using $0.5 \mu \mathrm{g} . \mathrm{mL}^{-1}$ of FSH with or without eCG supplementation, and similar percentages were achieved using $0.25 \mu \mathrm{g} . \mathrm{mL}^{-1} \mathrm{FSH}$ plus 15IU.mL ${ }^{-1}$ eCG during in vitro maturation. $\mathrm{FSH}$ and $\mathrm{eCG}$ could be used in combination, experimenting with various doses, in in vitro embryo production processes of alpacas for genetic improvement of this species.

\section{Acknowledgments}

We thank the staff of the National Institute of Agricultural Innovation (INIA) - Puno, Illpa Agrarian Experimental Station, Quimsachata Annex, for facilitating the in vitro Fertilization Laboratory, and the National Program of Agricultural Innovation (PNIA), Peru, research project 078_PI, for contributing to the execution of this study. An eternal thanks to Teodosio Huanca Mamani (R.I.P.) for guiding and supporting the study.

\section{Author's Contribution}

USQG and LVOM conceived, designed, executed, analyzed the data and wrote the manuscript. JCC and LEPF assisted in the design and execution of the research. M BC participated in the design and analysis of the research. JLB analyzed the data, assisted in the writing and editing of the manuscript. All authors approved final version of the manuscript.

\section{REFERENCES}

Aba MA, 2014. Chapter 14. Anatomy and Physiology of Reproduction in the Female Llama and Alpaca. In: Cebra C, Anderson DE, Tibary A, Van Saun RJ, Johnson LW (eds), Llama and Alpaca Care: Medicine, Surgery, Reproduction, Nutrition, and Herd Health. Elsevier, St. Louis, MO, USA, pp: 140-150. https://doi.org/10.1016/B978-1-4377-2352$\underline{6.00014-6}$

Blaschka C, Sánchez-Guijo A, Zimmer B, Stöhr J, Kotarski F, Grothmann H, Hartmann MF, Wudy SA and Wrenzycki C, 2019. Temporal expression pattern of steroid-metabolizing enzymes in bovine COC during in vitro maturation employing different gonadotropin concentrations. Theriogenology 131: 182-192. https://doi.org/10.1016/ j.theriogenology.2019.03.028

Brown BW, 2000. A review on reproduction in South American camelids. Animal Reproduction Science 58: 169-195. https://doi.org/10.1016/S0378-4320(99)00081-0

Choi YH, Carnevale EM, Seidel GE and Squires EL, 2001. Effects of gonadotropins on bovine oocytes matured in TCM-199. Theriogenology 56: 661-670. https://doi.org/10.1016/S0093-691X(01)00597-0

Conti M, Hsieh M, Park JY and Su YQ, 2006. Role of the epidermal growth factor network in ovarian follicles. Molecular Endocrinology 20: 715-723. https://doi.org/ 10.1210/me.2005-0185

Del Campo M, Del Campo C, Donoso M, Berland M and Mapletoft R, 1994. In vitro fertilization and development of llama (Lama glama) oocytes using epididymal spermatozoa and oviductal cell co-culture. Theriogenology 41: 12191229. https://doi.org/10.1016/0093-691X(94)90479-3

Di Rienzo JA, Casanoves F, Balzarini MG, Gonzalez LA, Tablada EM and Robledo CW, 2008. InfoStat Software Estadístico Manual del Usuario. Brujas, Córdoba, Argentina.

Fan HY, Huo LJ, Chen DY, Schatten H and Sun QY, 2004. Protein Kinase $\mathrm{C}$ and Mitogen-Activated Protein Kinase Cascade in Mouse Cumulus Cells: Cross Talk and Effect on Meiotic Resumption of Oocyte. Biology of Reproduction 70: 1178-1187. https://doi.org/10.1095/biolreprod.103.024737

Farag IM, Girgis SM, Zowail ME, Abd-Allah SM, El-Nahas EM and El-Hafez MAMA, 2012. Factors affecting in vitro maturation, yield and quality of camel (Camelus dromedarius) oocytes. Theriogenology Insight 2: 209-231.

Farag IM, Girgis SM, Zowail ME and El-Hafez MAMA, 2013. In vitro maturation of camel (Camelus dromedarius) cumulusdenuded oocytes. World Applied Sciences Journal 26: 352 359. https://doi.org/10.5829/idosi.wasj.2013.26.03.76208

Galli C and Moor RM, 1991. Gonadotrophin Requeriments for the In Vitro Maturation of Sheep and Their Subsequent Embryonic Development. Theriogenology 36: 1083-1093. https://doi.org/10.1016/0093-691X(91)90356-I

Hawk HW and Wall RJ, 1994. Improved yields of bovine blastocysts from in vitro produced oocytes. I. selection of oocyte and zygotes. Theriogenology 41: 1571-1583. https://doi.org/10.1016/0093-691X(94)90822-Z

Huanca W, Condori R, Chileno M, García P, Cainzo J and Becerra JJ, 2014. Evaluación de cuatro tiempos de cultivo sobre la tasa de maduración y división posfecundacion in vitro de ovocitos de alpaca. Revista de Investigaciones Veterinarias del Peru 25: 468-476. https://doi.org/10.15381/rivep. v25i4.10782

Leisinger C, Coffman E, Coutinho da Silva M, Forshey B and Pinto C, 2014. Factors affecting in vitro maturation of alpaca (Lama paco) oocytes. Animal Reproduction Science 150: 70-75. https://doi.org/10.1016/j.anireprosci.2014.08.011

Liang CG, Huo LJ, Zhong ZS, Chen DY, Schatten H and Sun QY, 2005. Cyclic adenosine 3',5'-monophosphate-dependent activation of mitogen-activated protein kinase in cumulus cells is essential for germinal vesicle breakdown of porcine cumulus-enclosed oocytes. Endocrinology 146: 4437-4444. https://doi.org/10.1210/en.2005-0309

Miragaya MH, Chaves MG and Agüero A, 2006. Reproductive biotechnology in South American camelids. Small Ruminant Research 61: 299-310. https://doi.org/10.1016/ j.smallrumres.2005.07.017

Murphy BD, 2012. Equine chorionic gonadotropin: an enigmatic but essential tool. Animal Reproduction 9: 223-230.

Murphy BD and Martinuk SD, 1991. Equine Chorionic Gonadotropin. Endocrine Reviews 12: 27-44. https://doi.org/10.1210/edrv-12-1-27

Mutembei HM, Mulei CM and PMF Mbithi, 2016. A cost-benefit analysis of usage of in-vitro embryo production and embryo 
Int J Vet Sci, 2021, 10(3): 156-161.

transfer technologies in cattle of Kenya. International Journal Veterinary Science 5: 64-68.

Nowshari MA 2005. The effect of harvesting technique on efficiency of oocyte collection and different maturation media on the nuclear maturation of oocytes in camels (Camelus dromedarius). Theriogenology 63: 2471-2481. https://doi.org/10.1016/j.theriogenology.2004.09.057

Ondho YS, Samsudewa D and Lestari DA, 2020. In vitro maturation of ovine oocytes using follicle stimulating hormone (FSH), estradiol-17 $\beta$ and co-culture of fallopian tube epithelial cells (FTEC) in tissue culture medium-199 (TCM-199). International Journal of Veterinary Science 9: 66-71.

Ratto M, Berland M, Huanca W, Singh J and Adams GP, 2005. In vitro and in vivo maturation of llama oocytes. Theriogenology 63: 2445-2457. https://doi.org/10.1016/ j.theriogenology.2004.09.053

Ratto M, Gomez C, Berland M and Adams GP, 2007. Effect of ovarian superstimulation on COC collection and maturation in alpacas. Animal Reproduction Science 97: 246-256. https://doi.org/10.1016/j.anireprosci.2006.02.002

Ruiz J, Santayana RP, Mendoza MJ, Landeo JL, Huamán E, Ticllacuri F, Mujica LF, Silva M and Ratto MH, 2017. Effect of oocyte maturation time, sperm selection method and oxygen tension on in vitro embryo development in alpacas. Theriogenology 95: 127-132. https://doi.org/10.1016/ j.theriogenology.2017.03.006

Salhab M, Tosca L, Cabau C, Papillier P, Perreau C, Dupont J, Mermillod P and Uzbekova S, 2011. Kinetics of gene expression and signaling in bovine cumulus cells throughout IVM in different mediums in relation to oocyte developmental competence, cumulus apoptosis and progesterone secretion. Theriogenology 75: 90-104. https://doi.org/10.1016/j.theriogenology.2010.07.014

Sansinena MJ, Taylor SA, Taylor PJ, Denniston RS and Godke RA, 2003. Production of Nuclear Transfer Llama (Lama glama ) Embryos from In Vitro Matured Llama Oocytes. Cloning and Stem Cells, 5: 191-198. https://doi.org/10.1089/ $\underline{153623003769645857}$

Santiquet NW, Develle Y, Laroche A, Robert C and Richard FJ, 2012. Regulation of gap-junctional communication between cumulus cells during in vitro: Maturation in swine, a gapFRAP study. Biology of Reproduction: 87: Artilce \# 46. https://doi.org/10.1095/biolreprod.112.099754

Songsasen N, Yu I, Gomez M and Leibo SP, 2003. Effects of meiosis-inhibiting agents and equine chorionic gonadotropin on nuclear maturation of canine oocytes. Molecular
Reproduction and Development 65: 435-445. https://doi.org/ 10.1002/mrd.10321

Sumar J, 2007. Chapter 113. Demographics and Herd Management Practices in South America. In: Youngquist R, Threlfall WR, Current Therapy in Large Animal Theriogenology, Elsevier, St. Louis, Missouri, USA, pp: 845-850.

Tibary A, Anouassi A and Khatir H, 2005. Update on reproductive biotechnologies in small ruminants and camelids. Theriogenology 64: 618-638. https://doi.org/ 10.1016/j.theriogenology.2005.05.016

Trasorras V, Baca Castex C, Alonso A, Giuliano S, Santa Cruz R, Arraztoa C, Chaves G, Rodríguez D, Neild D and Miragaya M, 2014. First llama (Lama glama) pregnancy obtained after in vitro fertilization and in vitro culture of gametes from live animals. Animal Reproduction Science 148: 83-89. https://doi.org/10.1016/j.anireprosci.2014.04.006

Wang X, Tsai T, Qiao J, Zhang Z and Feng HL, 2013. Impact of gonadotropins on oocyte maturation, fertilisation and developmental competence in vitro. Reproduction Fertility and Development 26: 752-757. https://doi.org/10.1071/ RD13024

Wani NA, 2021. In vitro embryo production (IVEP) in camelids: Present status and future perspectives. Reproductive Biology 21: 100471. https://doi.org/10.1016/j.repbio.2020.100471

Wei SC, Gong ZD, Zhao HW, Liang HQ, Lai LJ and Deng YY, 2016. Equine chorionic gonadotropin influence on sheep oocyte in vitro maturation, apoptosis, and folliclestimulating hormone receptor and luteinizing hormone receptor expression. Genetics and Molecular Research 15: 113. http://dx.doi.org/10.4238/gmr15049162

Wei S, Deng Y, Lai L, Liang H and Gong Z, 2018. Dosedependent effects of luteinizing hormone and follicle stimulating hormone on in vitro maturation, apoptosis, secretion function and expression of follicle stimulating hormone receptor and luteinizing hormone receptor of sheep oocytes. South African Journal of Animal Science 48: 369378. https://doi.org/http://dx.doi.org/10.4314/sajas.v48i2.18

Wei Suocheng, Gong Z, Sheng L, Liang H, Lai L and Deng Y, 2017. Maturation rates of oocytes and levels of FSHR, LHR and GnRHR of COCs response to FSH concentrations in IVM media for sheep. Journal of Applied Biomedicine 15: 180-186. https://doi.org/10.1016/j.jab.2017.01.001

Yang L, Wei Q, Li W, Xi Q, Zhao X and Ma B, 2016. NPR2 is involved in FSH-mediated mouse oocyte meiotic resumption. Journal of Ovarian Research 9: 1-7. https://doi.org/10.1186/s13048-016-0218-y 